\title{
Begravede dale på Sjcelland - Søndersø-, Alnarp- og Kildebrønde-dalene
}

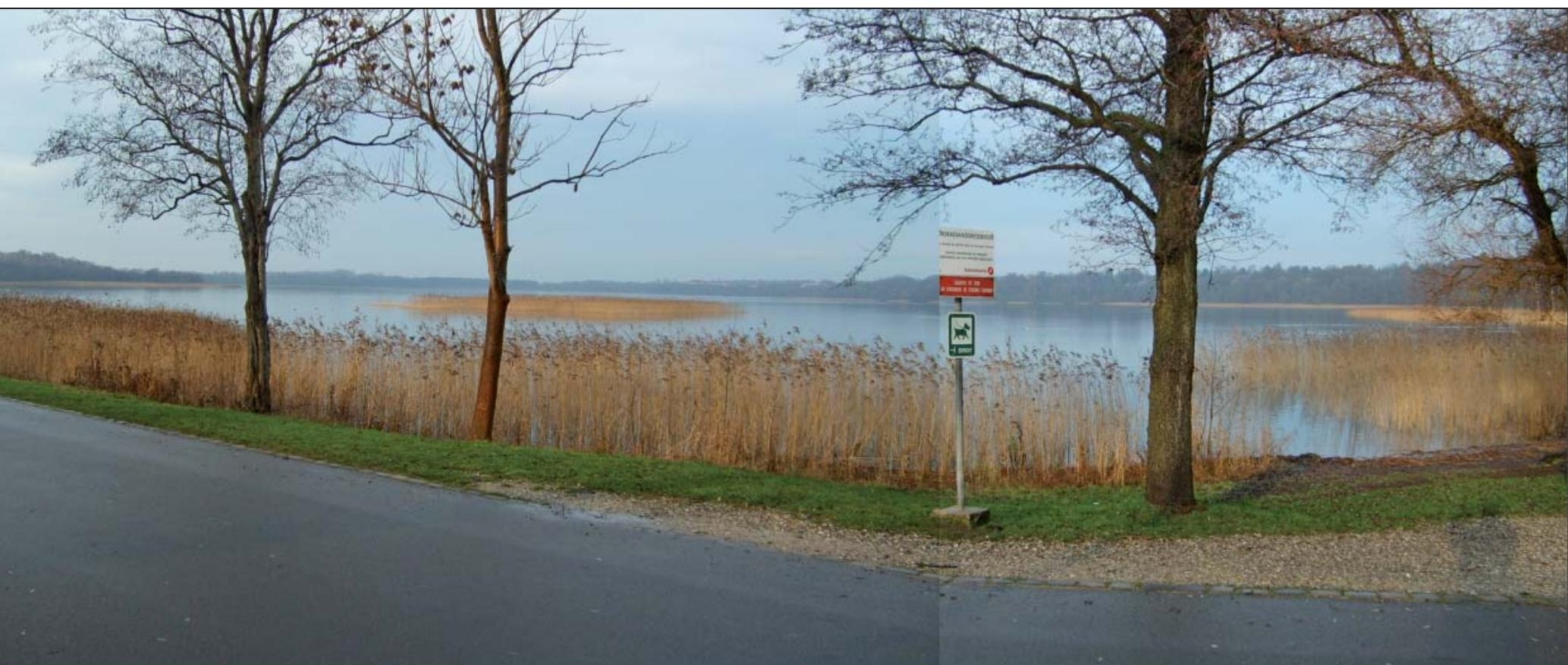

Søndersø en novemberdag i 2008. Søndersøen ligger ovenpå den begravede dal, Søndersø-dalen, ligesom en af de andre store søer i Danmark, Furesøen. Søernes tilstedevcrelse over den begravede dal har måske en sammenhæeng, men den er ikke belyst i denne artikel. Langs bredden af Søndersø ligger en hel serie af Københavns vandboringer, som indgår i dette studie. (Sammensat foto: Forfatteren)

Af Nick Svendsen

I Nordsjælland ligger der to begravede dale, Søndersø-dalen og Alnarp-Esrum-dalen. Begge dale har været kendt i over hundrede år. Ved Ishøj ligger ligeledes en begravet prækvartær dal, Kildebrønde-dalen. Dalene har ikke haft den store bevågenhed i senere tid, så lad os kigge lidt nærmere på dem.

De tilstedeværende geologiske data er vendt en ekstra gang for at forsøge at give en geologisk beskrivelse og en mulig dannelsesmodel for de begravede dale.

Det viste prækvarterkort, som er grundlaget for denne analyse, er modificeret fra Stenestad (1976), Bertelsen (1995), Wienberg Rasmussen (1966), Binzer og Stockmarr (1994), Schuldt (1980) samt Frederiksborg Amt (2003) (figuren øverst på næste side). Kortene er baseret på boringerne fra GEUS' boredatabase Jupiter, som vil være mange bekendt. Databasen indeholder lithologiske beskrivelser af de mange tusinde vandboringer og funderingsboringer, der er udført i Danmark i de sidste 100 år. Kvaliteten af de lithologiske beskrivelser varierer en del, men er gode nok til at bestemme dybden til prækvartæroverfladen. Kortet er understøttet af en serie af tværsnit.

\section{Prækvartæret}

Prækvartæret i Nordsjælland består overvejende af Danien-kalk bortset fra nogle mindre forekomster af palæocæn mergel på Amager, på Nordsjælland og under Københavns havn samt skrivekridt fra Maastricht ved Ishøj og på Stevns. Relieffet på den prækvartære overflade varierer fra ca. $30 \mathrm{~m}$ over havniveau til $60 \mathrm{~m}$ under havniveau. Det dybeste hul ligger ved Lyngby (figuren nederst på næste side og figuren øverst på side 22).

Hvis vi nærlæser Stenestads og Bertelsens kort, fremviser de flere steder snævre render, blandt andet Kildebrønde-dalen. Et tværsnit (tværsnit 1, figuren nederst på side 22), der løber fra Karlstrup i syd til Ishøj i nord, viser denne dal med et relief på op til 30 m, hvor Danien er blottet. I bunden af dalen findes Maastricht-kalk direkte under den kvartære moræne.

Ved Lyngby Sø er ligeledes vist dybe render, men stratigrafien af kalken i disse render er ikke bestemt nærmere end til at være Danien-kalk.

Mange af renderne har et uregelmæssigt relief. Flere steder viser kortene huller, der ikke er associeret med render.

\section{Søndersø-dalen}

Søndersø-dalen strækker sig fra Øresund i øst til Isefjorden i vest og er 2 til $3 \mathrm{~km}$ bred med en relativt flad bund og til tider stejle sider (tværsnit 2 og 3 på side 23). Bunden har kote $-30 \mathrm{~m}$ i øst og kote $-50 \mathrm{~m}$ i vest og hælder derfor mod vest. Søndersø-dalen fortsætter til Vestsjælland med områder, hvor Prækvartæret består af palæocæne aflejringer. Ved en undersøgelse af GEUS' borearkiv viser det sig, at der på Hornsherred ved Gershøj findes kalksten fra Danien i bunden af dalen og palæocænt mergel på kanterne af dalen (tværsnit 4 øverst på side 24). I Øresund møder dalen en anden dal, Alnarp-Esrum-dalen, der har en nordnordvestlig - sydsydøstlig orientering. Den er 
dybere, kote -50 til kote -60 (figuren nederst på denne side).

Dannelsen af Søndersø-dalsænkningen er omdiskuteret og 2 mulige modeller er fremført - en model relateret til grabendannelse (forkastningsbetinget) eller en erosionsbetinget model. De tilgængelige seismiske kort af dybereliggende lag viser ingen forkastninger i området ved Sødersødalen. Hvis dalen skulle være dannet ved forkastninger, burde den være parallel med områdets påviste forkastninger og passe ind i det regionale tektoniske mønster.

\section{Regionaltektonikken}

Lad os derfor se, hvad den regionale tektonik siger. Først og fremmest må dalene være dannet efter Danien, idet dalene jo er udformet i kalken, dvs. enten i Tertiær eller Kvartær. Vi må derfor se på disse perioders tektoniske aktivitet.

Sjælland ligger tæt på den Fennoskandiske Randzone, som har været aktiv siden Palæozoikum. Forkastningerne i randzonen stryger nordvest - sydøst. Bevægelserne i zonen har haft en sideværtskomponent ifølge Vejbæk (1997). Faktisk ligger der en større inversionsstruktur nordøst for Nordsjælland, hvori Kullen indgår (nederste figur på side 24). Denne struktur blev dannet som et resultat af transpressionsbevægelser (tranpression er et udtryk for, at området er blevet sammenpresset og at sammenpres-

Den prcekvartcre overflade i Nordsjcelland og Skåne efter flere forfattere samt Jupiter data basen. (Grafik: Forfatteren med tak til Mcersk Oil for tilladelse til at lave dette kort ved hjcelp af firmaets kortlceningssoftware.)

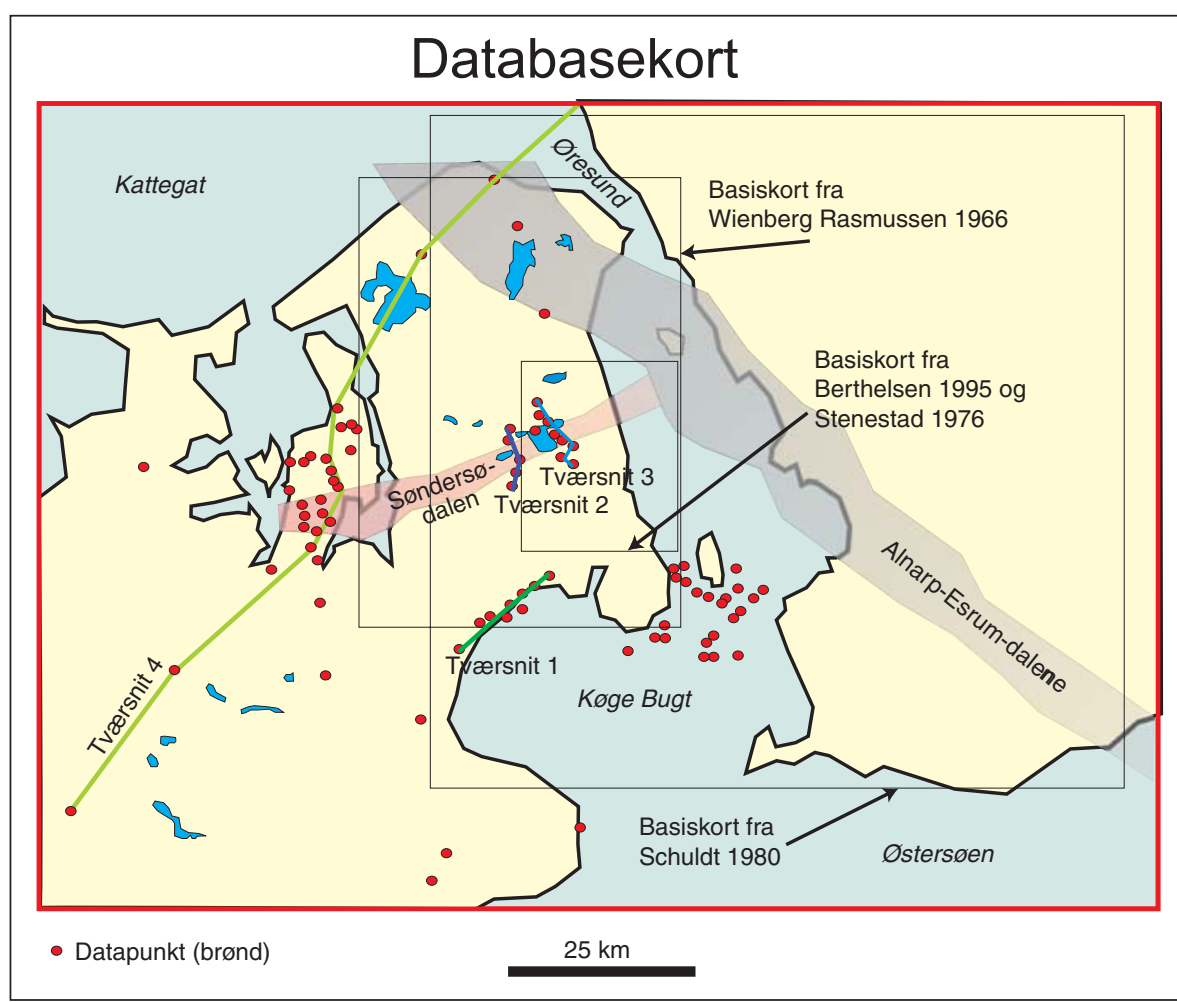

Databasekortet viser positionen af Søndersø-og Alnarp-Esrum-dalene, positionen af tvcrsnit samt brønd og kort, der er brugt til denne artikel. (Grafik: Forfatteren)

ningen, udover at have dannet inversionsstrukturen, også har givet sideværtsbevægelser i forkastningerne) i Campanien og tidlig
Maastrichtien samt i Palæocæn. Vi vil derfor forvente, at normalforkastninger vil have en strygning nord-syd og strikeslip-for-

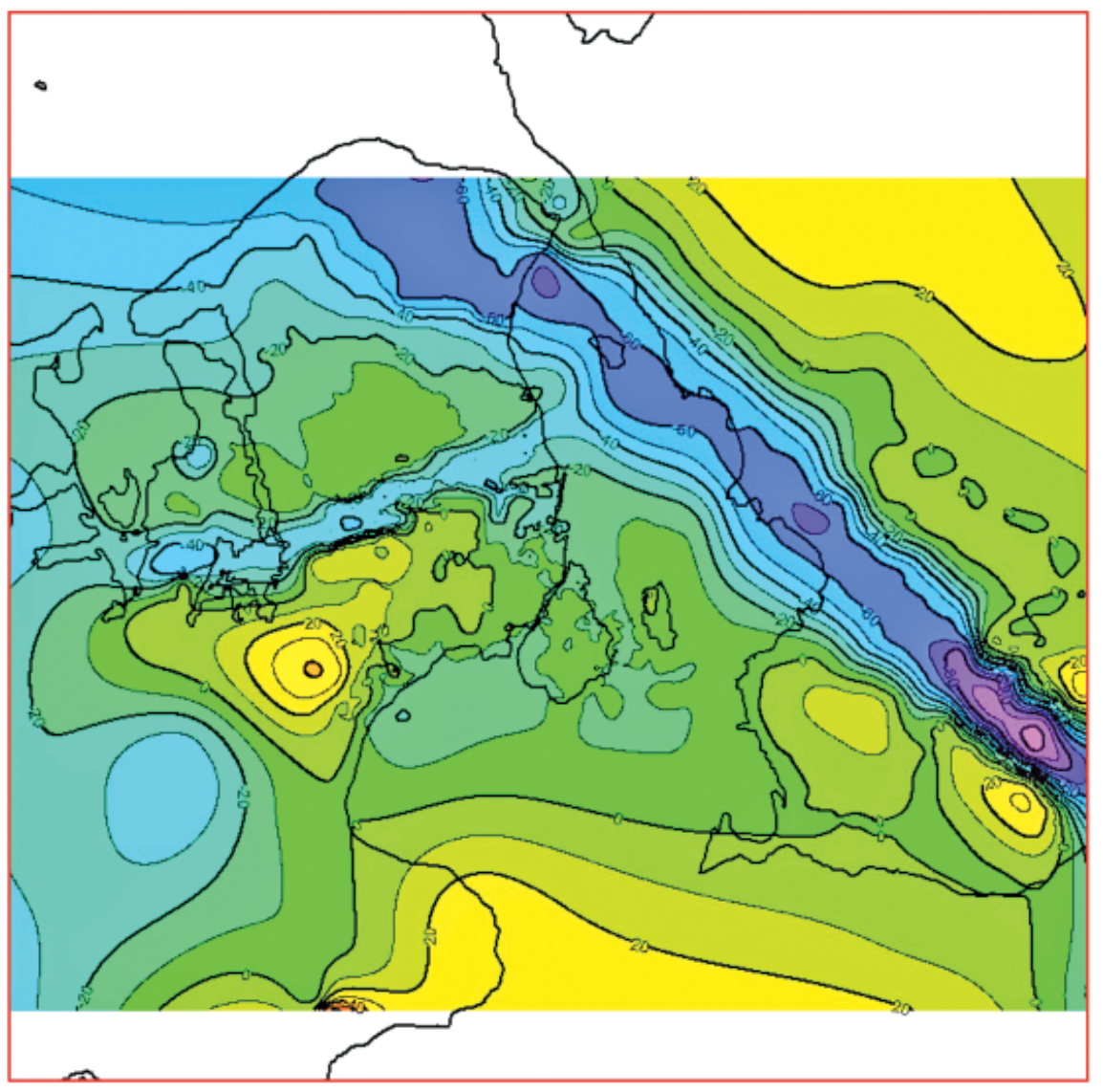


kastningerne nordvest - sydøst (parallelt til forkastningerne påvist i den Fennoskandiske Randzone). Carlsberg-forkastningen (synonym med Øresundsforkastningen) samt de andre mindre forkastninger i København og ved Roskilde samt normalforkastningerne i Køge Bugt (baseret på de derværende seismiske målinger) er orienteret næsten nord-syd. Søndersø-dalen ligger på tværs af denne orientering, hvilket antyder, at dalen ikke er opstået i forbindelse med inversionsstrukturens dannelse. De tektoniske kort, der er publiceret inden for de sidste 30 år (fx Vejbæk 1997) viser da heller ikke Søndersødalen.

\section{Alnarp-Esrum-dalen}

Nord for Søndersø-dalen ved Helsingør ligger den anden dalsænkning kaldet AlnarpEsrum-dalen. Ifølge Wienberg Rasmussen (1966) ligger der en lille rest af palæocæne sedimenter i dalen i Nordsjælland, og det er blevet brugt som argument for, at den også skulle være forkastningsbetinget. De findes i nogle boringer ved Mårum i Nordsjælland. Sedimenterne over Prækvartæret i dalen er blevet undersøgt af Schuldt i 1980, og det viser sig, at fyldet i dalen består af marine og fluviale sandaflejringer fra Weichsel.

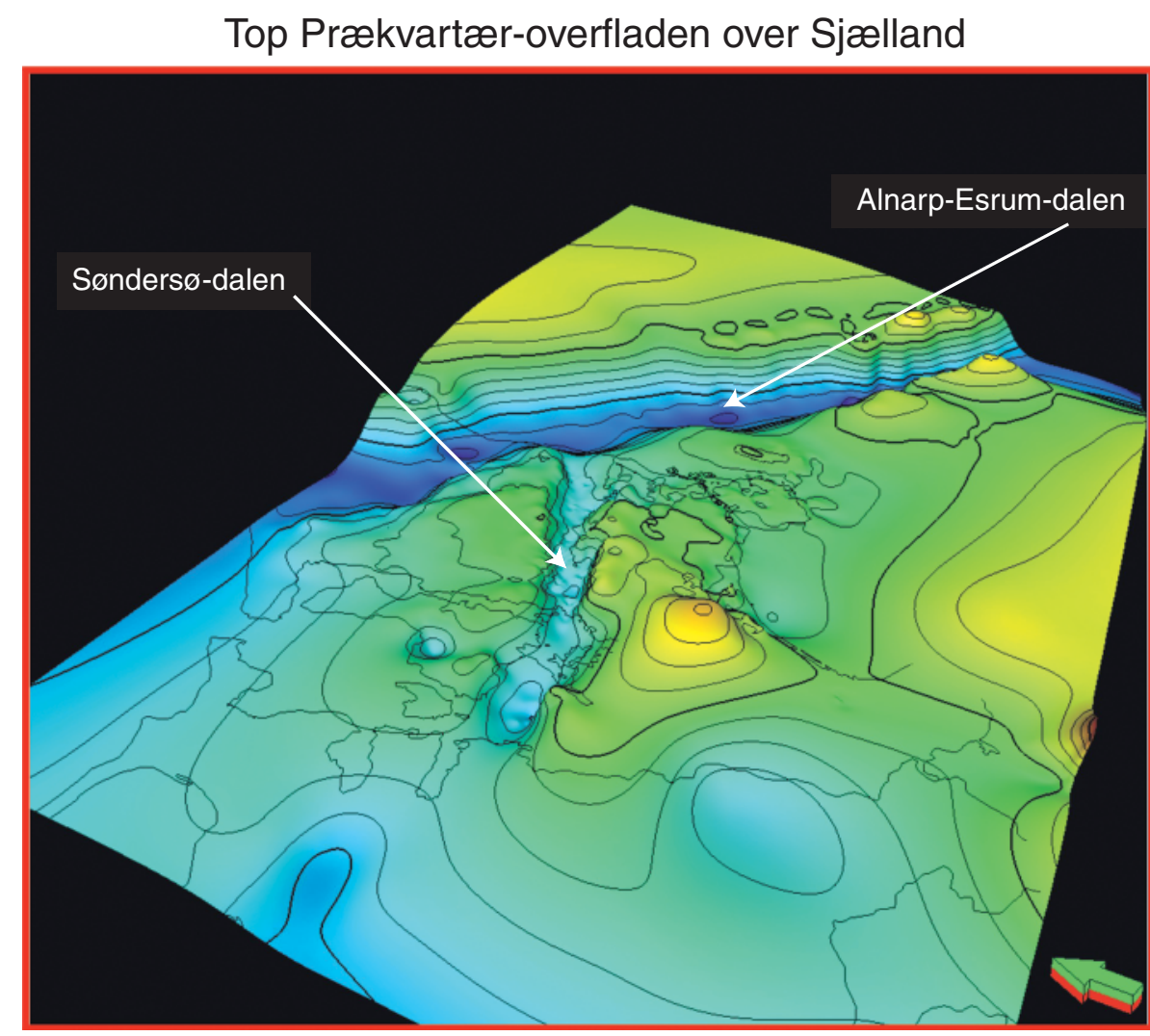

Toppen af den prckvartcere overflade på Sjcelland vist tredimensionelt. Det er det samme kort som i figuren nederst på foregående side med konturintervaller på $10 \mathrm{~m}$. Pilen i højre hjørne viser mod nord. (Grafik: Forfatteren)
De seneste publicerede seismiske tværsnit samt prækvartære strukturkort, der dækker Alnarp-Esrum-dalens beliggenhed, viser ingen tektonisk aktivitet siden Paleocæn ( $\mathrm{fx}$ Vejbæk, 1997). Det er derfor mere sandsynligt, at dalen er dannet overvejende ved ero- sion. Det udelukker ikke en hvis tektonisk aktivitet. Sandet i Alnarp-Esrum-dalen er dækket af Kattegat Till'en, og erosionen må derfor være foregået før dette gletscherfremstød. Man kunne tænke sig, at da gletscherne dannede Norskerende ved Sydnorge, æn-

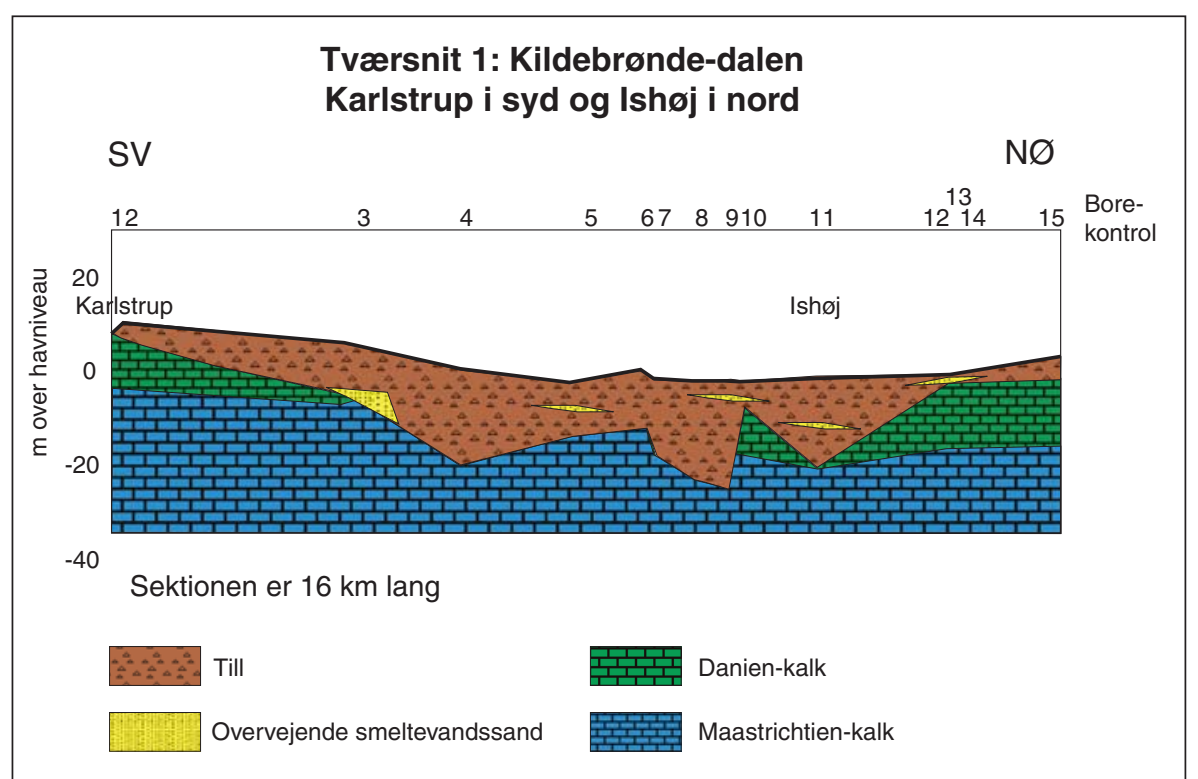

Tværsnit af Kildebrønde-dalen. Tvcersnittet starter ved Karlstrup i syd, hvor Danien og det øverste Maastricht er blottet i den tidligere kalkgrav. Man ser tydeligt, at Skrivekridtet ligger under morcenen ved Ishøj. Der er ikke umiddelbart nogen indikation på en forscetning af kalken i forbindelse med dalen. Den fortolkes derfor som en erosionsdal. Dalen skråner mod øst, hvilket antyder, at afvandingen af dalen må have løbet mod øst. (Grafik: Forfatteren) 
drede dræningsmønstret sig fra overvejende øst-vest til overvejende nord-syd. Derved blev Søndersø-dalen afsnøret og fungerede ikke mere. Så selvom Alnarp-Esrum-dalen overvejende er en erosionsdal, så har de strukturelle elementer spillet med - i dette tilfælde Söder-Rommel Åsen - og styret retningen af erosionen.

\section{Erosion}

Der er i de senere år påvist flere begravede erosionsdale i andre dele af Danmark, som både er af kvartær og tertiær alder (fx Huuse og Lykke-Andersen, 2001). I Nordsøen kan man observere flere sedimentære sekvenser af tertiær alder, som prograderer fra øst mod vest. Dette nævnes som evidens for, at den østlige side af Danmark samt Sverige var hævet og udsat for erosion med materialetransport fra øst mod vest. Havet nåede i Oligocæn og Miocæn ikke til Sjælland.

Den prækvartære overfladen i Nordsjælland har derfor været eksponeret siden Eocæn.

Kildebrønde-dalen, hvor Maastricht-kalken er eksponeret i bunden og uden antydning af større forsætning af selve kalken på hver side af dalen, er ligeledes en erosionsrende. Kildebrønde-dalen er orienteret på tværs af eksisterende tektoniske trends.

Søndersø-dalen med de snævre render og mindre huller har erosionsrester af palæocænt mergel på begge sider af dalen ved Gershøj, hvilket antyder, at dalen er dannet ved erosion. Det foreslås derfor, at Søndersø-dalen er en begravet erosionsdal med tilhørende sidedale, som for eksempel Kildebrønde-dalen. Spørgsmålet er så tidspunktet for erosionen. Som nævnt ved vi, at området var hævet i den senere del af Tertiær, og der er ikke noget i vejen for, at dalene er dannet ved vandløbserosion i den senere del af Tertiær. Klimaet i Miocæn var varmt, og hullerne kan derfor være jordfaldshuller dannet som en karst. Stenestad (2006) beskriver et karstsystem i kalken ved Rørdal i Nordjylland, som udmærket kan anses for en parallel til det, vi ser i kalkoverfladen ved København. Rørdal-karsten er fyldt med kvartært sand ligesom Søndersø-dalen.

Der er ingen tvivl om, at de kvartære gletschere senere har høvlet toppen af kalken, og smeltevandsfloderne har fulgt de etablerede dræningsmønstre og derved modificeret relieffet yderligere. Fyldet i Søndersø-dalen består af fluvialt sand og leraflejringer, mens Kildbrønde-dalen ikke indeholder smeltevandssand i større målestok. Hvis vi studerer Binzer og Stockmarrs kort fra 1997, som dækker hele Danmark, får man ligeledes indtrykket af en erosionsflade med dybe render.

Kortet indeholder dog en skønhedsfejl - det viser den smalle del af Roskilde Fjord som en prækvartær dal. De boringer, jeg har undersøgt langs fjorden, giver ikke belæg for en sådan fortolkning. Kortet fra Fredriksborg Amt (2005) viser da heller ikke

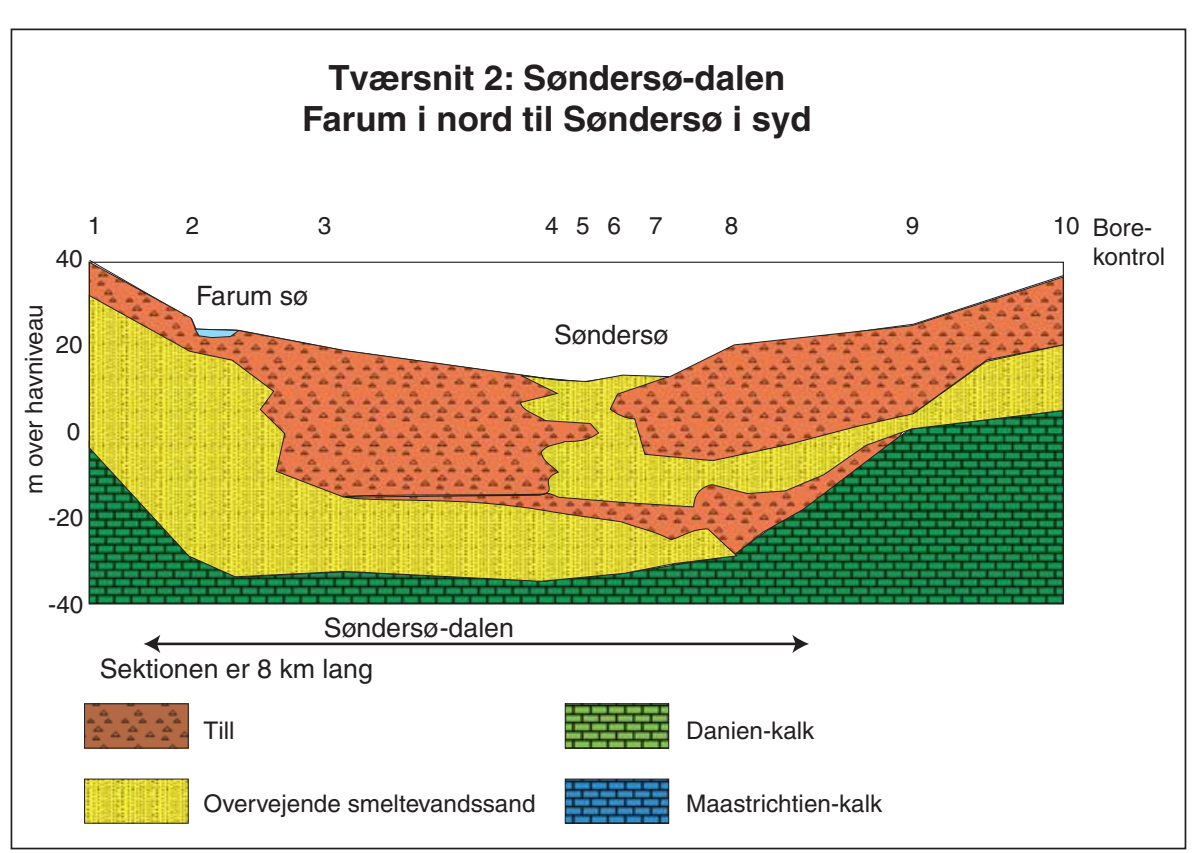

Tvœersnittet skcrer øst om Søndersø. (Grafik: Forfatteren)

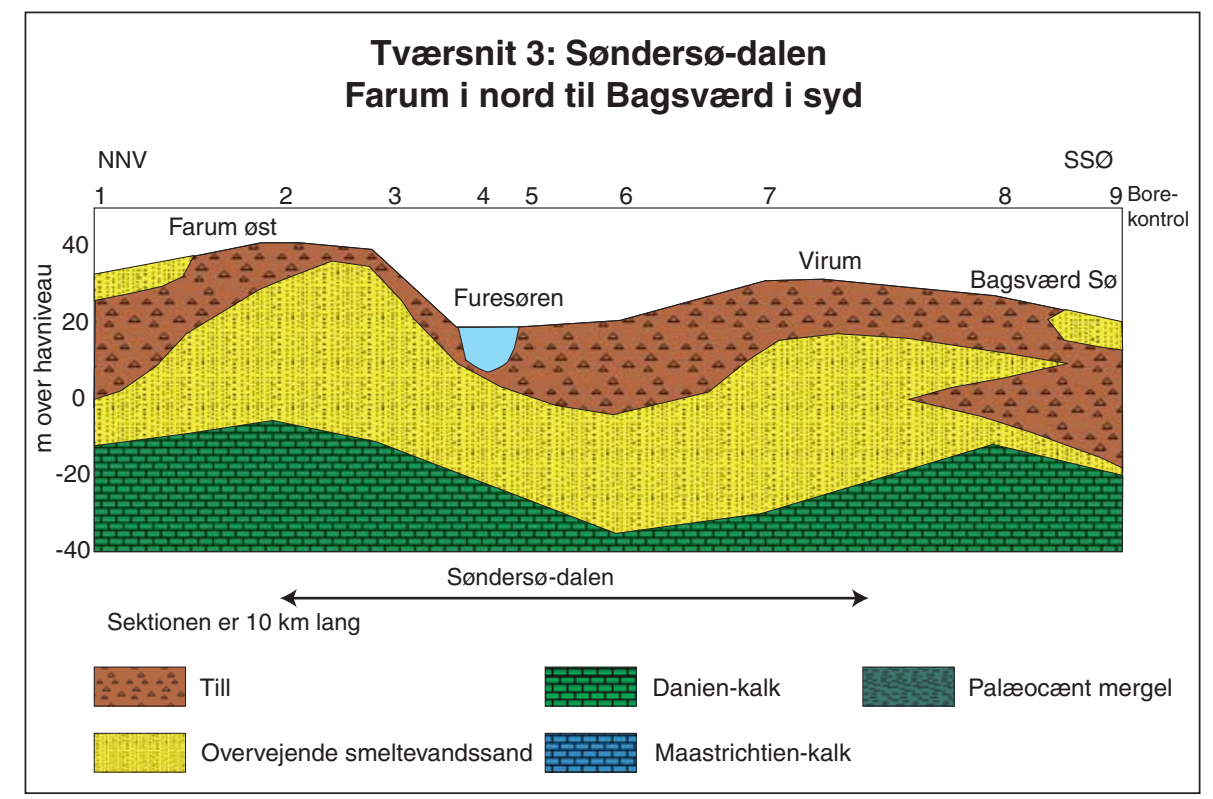

Tvœrsnittet skcrer Furesøen ved Store Kalv. Dalen har relativt jæevne skråninger i dette område. Man bemcerker de massive smeltevandsaflejringer i området. Selve Furesøens dannelse skal ikke berøres her, men er formentlig et dødishul dannet i forbindelse med det sidste gletscherfremstød. (Grafik: Forfatteren)

nogen prækvartær dal ved Roskilde Fjord. Til gengæld kan den indre del af Roskilde Fjord være et udtryk for den underliggende Søndersø-dal.

\section{Følgende model foreslås:}

1. Nordsjcelland var hæevet over havet i den sene del af Terticer. De smalle dale peger på det viste drceningsmønster. Klimaet var varmt og fugtigt, og der blev dannet en karstoverflade. Søndersø-dalen blev dannet ved vandløbserosion. Dalen hrelder mod vest, og vandet har derfor løbet mod vest.

2. I Kvartær fulgte smeltevandsfloderne dalen, og der blev aflejret smeltevandssand $i$ nogle af dalene.

3. Senere rykkede gletscherne hen over området og høvlede toppen af kalken.

4. Dalene fyldtes med till og dødis.

5. Norske Rende blev dannet.

6. Alnarp-Esrum-dalen dannedes som resultat af cendrede drceningsmønstre og fyldtes med sand, der kom fra afløbet fra den Baltiske Issø. Havet transgrederede i en periode over den nordlige del af dalen.

7. I den sene del af afsmeltningen af indlandsisen fulgte afløbet fra Østersøen først Øresund og siden også Storebcelt og Lillebcelt. 


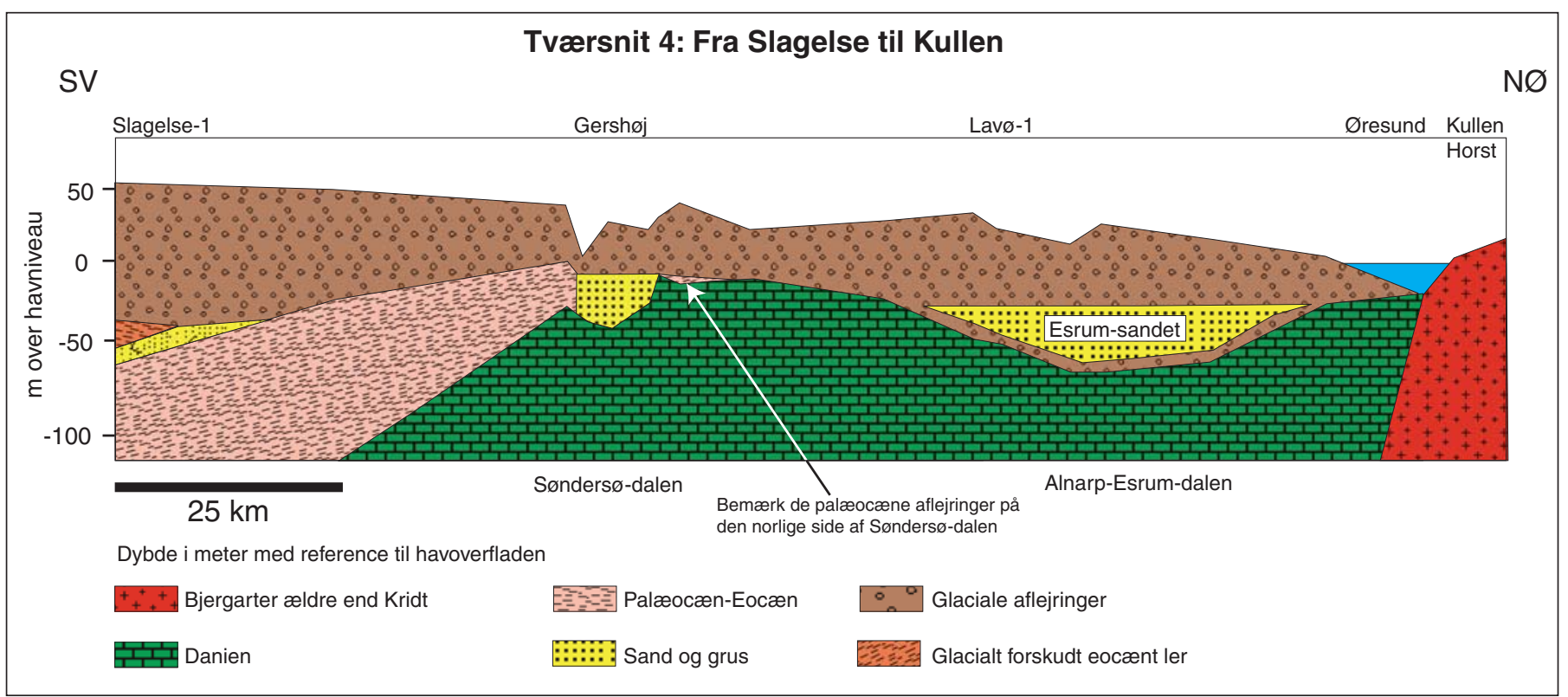

Tvœrsnit fra Slagelse i syd til Kullen i nord. Tvœrsnittet er baseret på boredata samt Prckvatcerkortet. (Grafik: Forfatteren)

Denne model foreslår en ikke-tektonisk oprindelse af Søndersø-, og Kildebrøndedalene. En detaljeret undersøgelse af fyldet i dalene kan måske afgøre tidspunktet for dalenes dannelse, Miocæn/Pliocæn eller Pleistocæn.

\section{Referencer:}

Bertelsen O. 1995, Fra det nordlige Sokkelund - noget om geologi, teglværker, grusgrave og tørveskcering. DGU

Binzer, K. og J. Stockmar, 1994, Geologisk kort over Danmark, 1:500000, Prckvartceroverfladens højdeforhold. DGU Kortserie Nr. 44

Frederiksborg Amt, 2005, Grundvandsatlas for Frederiksborg Amt.

Huuse, M. og.Lykke-Andersen, H., 2001, Begravede dale i N. V. Europa - dannet under indlandsisen. GeologiskNyt 1/01 Rosenkrantz, 1937, Bemæerkninger om det østsjeellandske Daniens Stratigrafi og Tektonik. DGF Bd. 9 h. 2

Schuldt, 1980, Om Esrumdalens geologi. DGF Årskrift 1980

Stenestad, 1976, Københavnsområdet geologi, iscer baseret på citybaneundersøgelserne. DGU, III Rk. Nr. 45

Stenestad E. 2006, Fluviokarst in the top of the Maastrichtian chalk at Rørdal, Northern Jutland, Denmark Bull. Geol Soc. Denmark Vol. 53, 93-110

Vejbcek, O. V. 1997, Dybe strukturer i danske sedimentcere bassiner. Geologisk Tidsskrift hrefte 4.

Wienberg Rasmussen, H. 1966, Danmarks Geologi Gjellerup

Jeg vil gerne takke Maersk Oil for hjælp og støtte til publikation af denne artikel.

\section{Simplificeret tektonisk kort over Danmark}

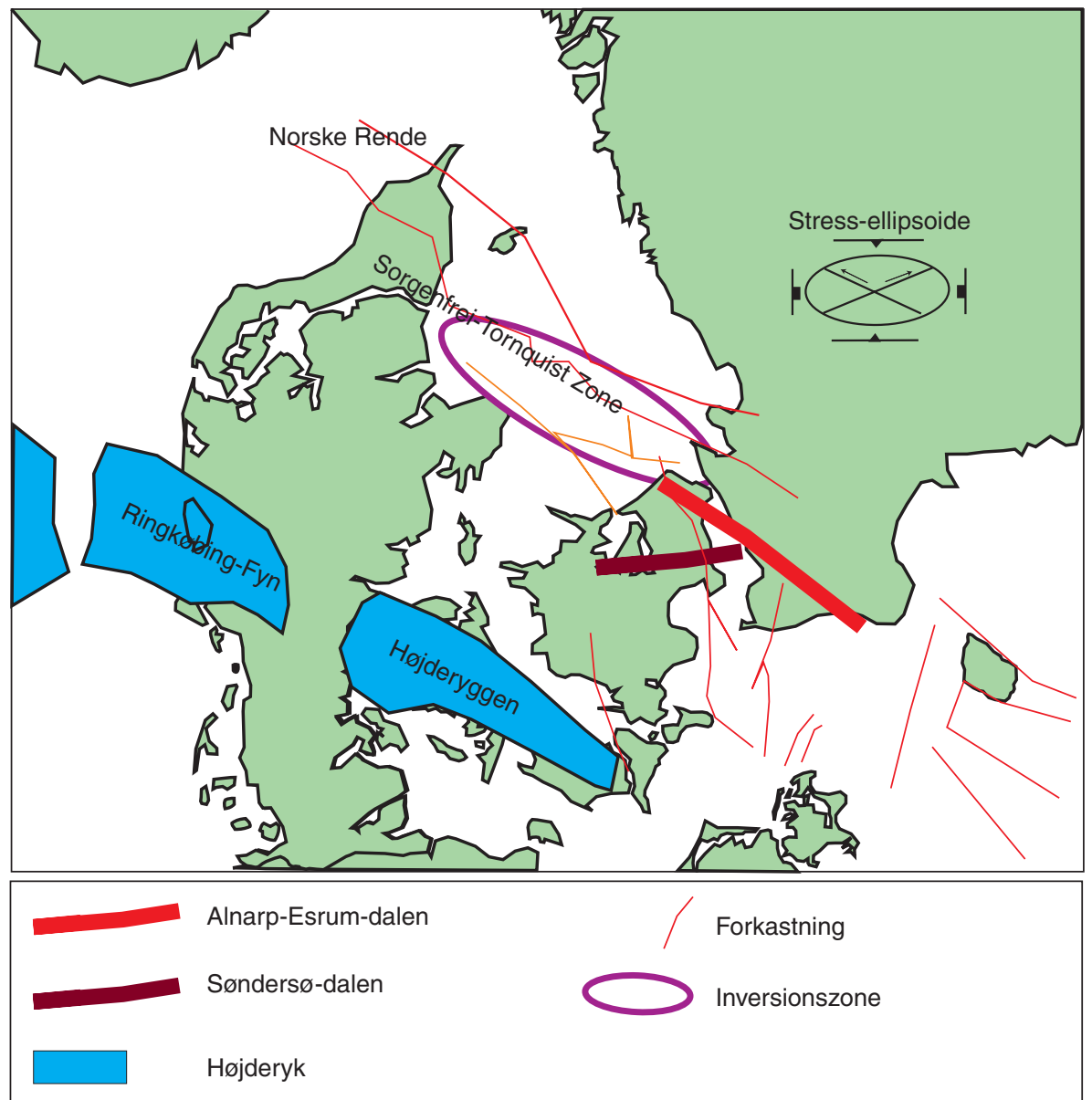

Simplificeret tektonisk kort over Danmark, der viser positionen af Søndersø-dalen og Alanarp-Esrum-dalen i forhold til de strukturelle trends. Stress-ellipsoiden viser retningen på sammenpresningen og de deraf resulterende retninger på normal-forkastninger, reverse forkastninger og sidevcertsforkastninger. Da sammenpresningen er nord-syd, vil normalforkastningerne ligge parallelt orienteret til retningen af sammenpresningen, de reverse forkastninger vinkelret på og sidevœrtsforkastningerne ligge med en vinkel på ca. $45^{\circ}$ i forhold til den principielle stressretning, som er sammenpresning. (Grafik: Forfatteren) 